\title{
A risk management methodology for protozoa control in drinking water supply systems
}

\author{
A. A. L. S. Duarte, J. L. Teixeira \& J. M. P. Vieira \\ Department of Civil Engineering, University of Minho, Braga, Portugal
}

\begin{abstract}
Over the last two decades, enteric protozoa have been recognized as a major concern regarding waterborne diseases, mostly due to the occurrence of a high number of outbreaks worldwide, leading to serious public health problems. The complexity of these problems advises an integrated analysis of the microorganisms' characteristics and life cycle linked with the catchment-toconsumer drinking water system in order to bring light upon the failures that underlie these undesirable events.

Several studies have been developed in order to mitigate these impacts on public health, attending to the main paths of water contamination, and the processes of advanced treatment and monitoring. Moreover, risk management methodologies were also improved in order to provide the incorporation of the multiple barrier approach in drinking water risk assessment tools, which must be able to identify hazards and the major vulnerabilities of drinking water contamination by pathogenic protozoa.

In this work, the authors present a protozoa control strategy, based on a risk management methodology and consisting of three fundamental steps: identification of hazardous events and drinking water system failures; qualitative risk assessment associated with the identified events and failures; definition of risk mitigation measures for protozoa control. A case study will be used for testing the proposed methodology towards the design of a strategic plan to minimize the resilience of the events related to the presence of these pathogens in water sources and to increase the sustainability of water resource management. Keywords: safe drinking water, water sources protection, protozoa control, risk management, fault tree analysis.
\end{abstract}




\section{Introduction}

The Giardia protozoa have been known to be a human parasite for more than 200 years with the capacity for transmission through the ingestion of contaminated water since the 1960s [1]. However, it was only in the 1990s that the pathogenic protozoa acquired the status of a serious public health hazard. In Milwaukee outbreak of 1993, malfunctioning water filters caused an outbreak of the enteric protozoan Cryptosporidium that infected 403,000 people. Of these, 100 people died, 4400 were hospitalized and 44,000 required medical care [2-4]. According to the World Health Organization (WHO) [5] the Milwaukee outbreak had a total cost of illness close to US\$ 96.2 million.

Ever since, there has been a growing interest in these microorganisms and several other outbreaks were studied and related. A total of 325 outbreaks were registered all over the world until 2007 [1, 2, 6, 7]. Nonetheless, these might not represent the real number of outbreaks which occurred because, even in Europe and America, only a few countries have a reliable outbreak surveillance system [1].

Even so, the analysis of the recorded cases allowed a few conclusions that were mostly related to the following protozoa characteristics:

- There are several pathogenic protozoa capable of inducing waterborne infection in humans;

- $\quad$ These parasites are encase in thick-walled cysts and oocysts with much reduced sizes that make their removal by size exclusion difficult [5];

- They present low host specificity and are excreted in great numbers by their hosts, increasing the potential for environmental spread and contamination [7];

- The protozoa possess high survival rates in the water and great resistance to the most common processes of water treatment, namely disinfection processes [8];

- Their direct monitoring requires costly and not totally reliable processes [6];

- The usual faecal indicators are not suitable to indicate the presence of protozoa in the water mainly because the first present lower survival rates in the aquatic environment and less resistance to different water treatment processes than the latter [8];

- There is no proven correlation between protozoa concentration in water and the concentrations of other organisms or water characteristics. This makes it difficult to assess the presence and fluctuation of protozoa in raw water [9].

When combining all of the above with the fact that end-product testing can only show water quality deviations after the consumption of the water, the need for an additional approach to ensure the quality and safety of drinking water regarding these parasites was acknowledged [10]. Hence, the conclusion was reached that the safety of drinking water against pathogenic protozoa needed a preventive, rather than reactive, approach based on a risk management strategy capable of taking into account the multi-barrier approach $[5,10,11]$. 

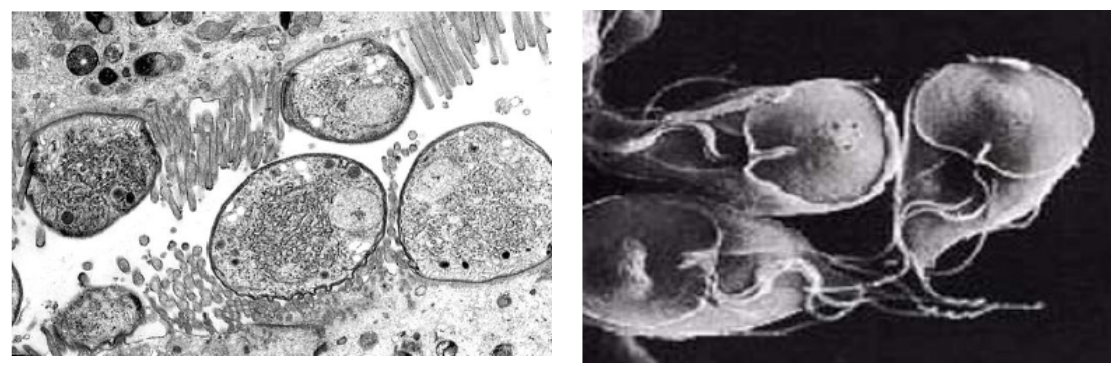

Figure 1: $\quad$ Microscopic view of protozoa Cryptosporidium parvum (left) and Giardia lamblia (right).

This strategy must consider all the events that concur to the risk itself presence of enteric protozoa in drinking water - and detect ways of reducing it [3]. With this goal, numerous studies were developed to understand how these parasites occur in nature, their transport to superficial water and behavior when submitted to different water treatment processes. The outcome of such research was used to develop the presented strategy for risk management, which consists of three fundamental steps: identification of hazardous events and drinking water system failures, qualitative risk analysis associated to the identified events and failures, and definition of risk mitigation measures for protozoa control. It takes into consideration the multi-barrier approach, as stated, by considering two adjoined phases: (1) protection of surface water; (2) water treatment against pathogenic protozoa.

\section{Risk management methodology}

\subsection{Risk identification}

This first step of the proposed risk management methodology includes the identification of all the hazardous events that can generate risk of the presence of pathogenic protozoa in drinking water [12]. This was carried out through careful analysis of the studies mentioned above, namely, by the evaluation of past events.

These studies focused on diverse subjects such as the relations between soil use and oocysts in surface water [9], more specifically the impact that agriculture or livestock have in its presence and concentration [9, 13-17], and the contribution of wild life [8].

Other authors measured the variation in oocyst concentration in surface waters caused by sewer discharges [18] and by combined sewer overflows (CSO) [19].

The influence of rainwater or snow melting in the transport of oocysts to surface waters $[9,20-22]$ and the effectiveness of the removal or inactivation of these parasites by filtration $[1,5,7,10,11,14,23,24]$ and/or disinfection $[1,5$, $10,11,14,22,24]$ were also largely evaluated in several scientific studies. 
This review identified several hazardous events contributing to the actual possible risk. Hereupon, the hazardous events identified were divided into two groups: the ones that lead to surface water contamination, and the ones that result in ineffective water treatment against these parasites. The first group is presented in Table 1. Please note that most of the events presented do not, solely, produce the risk of contaminating surface waters with pathogenic protozoa. Instead, they need to occur in combination with other events, here identified as complementary events. This interconnection is also shown in Table 1.

Table 1: Hazardous events - surface water contamination.

\begin{tabular}{|c|c|c|c|c|}
\hline \# & Hazardous event & Cause & $\begin{array}{c}\text { Complementary } \\
\text { events }\end{array}$ & References \\
\hline 1 & Presence of lives tock (cattle) & \multirow{5}{*}{$\begin{array}{l}\text { (Oo)cist excretion by } \\
\text { infected animals }\end{array}$} & 5 or 8 & {$[1,13,14,15,16,17]$} \\
\hline 2 & Presence of livestock (sheep) & & 5 or 8 & {$[1,14,15,17,20]$} \\
\hline 3 & Pres ence of livestock (pigs) & & 5 or 8 & {$[1,14,15,17]$} \\
\hline 4 & $\begin{array}{l}\text { Presence of wild life (including } \\
\text { waterbirds) }\end{array}$ & & 5 or 8 & {$[1,7,8,13,14,17]$,} \\
\hline 5 & Direct animal access to water & & - & {$[13,14,16,17,20,24,25]$} \\
\hline 6 & $\begin{array}{l}\text { Depositions of animal faeces on the } \\
\text { soil }\end{array}$ & \multirow{2}{*}{$\begin{array}{c}\text { Animal feaces are } \\
\text { available for transport }\end{array}$} & 8 & {$[1,14,15,17,20]$} \\
\hline 7 & Manure storage and application & & 8 & {$[15,17,20,25]$} \\
\hline 8 & Raiwater or snowmelting & \begin{tabular}{|l|} 
Help (oo)cists transport \\
and dispersion
\end{tabular} & - & {$[1,7,15,16,20,21,22]$} \\
\hline 9 & Presence of infected humans & \multirow{6}{*}{$\begin{array}{l}\text { (Oo)cist excretion by } \\
\text { infected humans }\end{array}$} & - & {$[5,9]$} \\
\hline 10 & Treated sewage discharge points & & 9 & {$[7,13,14,17,18,24,25]$} \\
\hline 11 & Untreated sewage discharge points & & 9 & {$[7,14,17,19]$} \\
\hline 12 & $\begin{array}{l}\text { Sewage systems' and STP's lack of } \\
\text { capacity }\end{array}$ & & - & {$[7,17,19,25]$} \\
\hline 13 & $\mathrm{CSO}$ & & 8 and 9 and 12 & {$[7,14,17,19,25]$} \\
\hline 14 & Boat latrines discharge & & 9 & [25] \\
\hline
\end{tabular}

An adequate risk assessment procedure, aimed at understanding which of the factors listed in Table 1 occurs and what their relative weights are, implies that a sanitary survey should be taken for the watershed under study $[1,10,17]$. When assessing the events' relative weight it is important to consider seasonal factors such as cattle birth season, since young animals are more prone to infection [1, $17,20]$. Local factors, such as steeper land slopes or lesser vegetation at the point of occurrence of the hazardous event, can promote easier oocyst transport [24].

The second group of hazardous events, the ones that cause ineffective water treatment against protozoa includes the absence of effective treatment processes against these parasites or the failures/inefficiency of theoretically effective processes.

The most common water treatment failures, like equipment malfunction, power outages, monitoring equipment failures, lack of personnel response $[1,7$, $11,25]$, are included in the failures of water treatment against protozoa. 
However, some failures more than others promote the potential presence of these parasites in drinking water. These are listed in Table 2.

Table 2: $\quad$ Hazardous events - water treatment.

\begin{tabular}{|c|c|c|c|}
\hline \# & Hazardous events & Cause & References \\
\hline 1 & Absence of water treatment & All parasites present in drinking water & {$[1,5,26]$} \\
\hline 2 & Disinfection only & Little or no effective against protozoa & {$[1,7,20,23,26]$} \\
\hline 3 & $\begin{array}{l}\text { No filtration (or existence of } \\
\text { filtration bypasses) }\end{array}$ & $\begin{array}{l}\text { Due to the little effectiveness of the } \\
\text { disinfection process, size exclusion is the }\end{array}$ & {$[1,7,20,23,26]$} \\
\hline 4 & Direct granular or sand filtration & $\begin{array}{l}\text { Protozoan parasites are smaller than the pore } \\
\text { size of the filters and the adsorption process }\end{array}$ & {$[7,20,26]$} \\
\hline 5 & $\begin{array}{l}\text { Little resilience of water } \\
\text { treatment processes }\end{array}$ & Raw water quality varies & {$[1,8,11,25,26]$} \\
\hline 6 & Poor dose of coagulant & $\begin{array}{l}\text { "An optimal coagulation dose is the most } \\
\text { important factor for ensuring effective } \\
\text { removal of cysts and oocysts by } \\
\text { sedimentation and filtration" }[38, \text { pp. 16] }\end{array}$ & {$[1,7,11,23,25,26]$} \\
\hline 7 & Inadequate coagulant & \multirow{2}{*}{$\begin{array}{l}\text { Flakes do not form properly for removal by } \\
\text { clarification and/or filtration }\end{array}$} & {$[7,23,25,26]$} \\
\hline 8 & Insufficient flocculation & & {$[11,25,26]$} \\
\hline 9 & $\begin{array}{l}\text { Water passing trough recent } \\
\text { washed granular or sand filters }\end{array}$ & $\begin{array}{l}\text { Filters need some period after their washing } \\
\text { so to start functioning properly }\end{array}$ & {$[1,7,20,26]$} \\
\hline 10 & Recycling water from filter wash & $\begin{array}{l}\text { The parasites initially removed by the filter } \\
\text { may go through it after washing }\end{array}$ & {$[1,7,11,26]$} \\
\hline
\end{tabular}

Besides identifying the most problematic failures in water treatment processes, it is also of importance to know the effectiveness exhibited by the most commonly used treatment processes when directed towards the removal/inactivation of pathogenic protozoa. A qualitative rating of this effectiveness is presented in Table 3.

The combination of these aspects will enable a sensitivity analysis of the safety of drinking water regarding this threat by comparing the expected raw water quality to the water treatment expected performance.

\subsection{Risk analysis}

Risk analysis consists of understanding risk [12, 27-29]. This step of the risk management strategy uses all the elements identified in the earlier stage and provides a basis for decision making relating risk treatment.

A risk analysis methodology was developed in order to promote a qualitative study for the presence of pathogenic protozoa in drinking water, in order to obtain a sensitivity analysis of this risk and from it, devise ways to minimize it. The qualitative analysis is often employed before a more detailed analysis, such as quantitative analysis, to obtain general information about the level of the identified risk [27]. Thereby, it is best suited to the Portuguese scenario where there are few valid numerical data available regarding the presence of these 
Table 3: $\quad$ Effectiveness of water treatment processes.

\begin{tabular}{|c|c|c|c|}
\hline Water treatment process & Characteristics & $\begin{array}{l}\text { Protozoan } \\
\text { removal or } \\
\text { inactivation }\end{array}$ & References \\
\hline \multirow{5}{*}{ Disinfection } & Chlorine & $\mathrm{x}$ & {$[1,11,20,22,23,26]$} \\
\hline & Chlorine dioxide & - & {$[11,20,22,26]$} \\
\hline & Chloramines & - & {$[11,20,22,23,26]$} \\
\hline & Ozone & + & {$[1,11,20,23,26]$} \\
\hline & U.V. & + & {$[11,20,22,23,26]$} \\
\hline Direct granular filtration & Without previous clarification & + & {$[1,11,26]$} \\
\hline \multirow{2}{*}{$\begin{array}{l}\text { Coagulation/Flocculation }+ \\
\text { Sedimentation }\end{array}$} & With alum as coagulant & + & {$[1,26]$} \\
\hline & With ferric coagulants & + & [26] \\
\hline \multirow{2}{*}{$\begin{array}{l}\text { Coagulation/Flocculation }+ \\
\text { Dissolved air flotation }\end{array}$} & With ferric coagulants or alum & + & {$[23,26]$} \\
\hline & $\begin{array}{l}\text { With polyelectrolyte coagulant to } \\
\text { stabilize flocculation }\end{array}$ & ++ & [26] \\
\hline \multicolumn{2}{|c|}{ Coagulation/Flocculation + High rate sedimentation } & ++ & [26] \\
\hline \multicolumn{2}{|l|}{ Slow sand filtration } & ++ & {$[1,6,14,20,26]$} \\
\hline \multicolumn{2}{|c|}{$\begin{array}{l}\text { Coagulation/Flocculation }+ \text { Sedimentation/Flotation }+ \text { Granular } \\
\text { filtration }\end{array}$} & $+1+$ & {$[1,6,11,14,23,26]$} \\
\hline \multicolumn{2}{|l|}{ Membrane filtration } & +++ & {$[1,11,20,26]$} \\
\hline
\end{tabular}

parasites in raw and treated water. Consequently, to develop this approach several methods suited for quantitative analysis with possible application in the field of microbiologic water quality were studied. These are compiled in Table 4. Each method's fundamental characteristics are presented together with their applicability to both source quality and treatment effectiveness of drinking water supply systems. The risk analysis methodology will also be divided in this two phases, each one having its own risk analysis method.

After studying several of the available methods (REFS), the authors chose to use a Fault Tree (FT) for analyzing the risk of the presence of pathogenic protozoa in source waters, and an Event Tree (ET) to analyze the risk associated with the water treatment systems.

An FT is a logic diagram that shows the relation between one specific undesirable event and all the system's failures, allowing their identification $[29,30]$.

As stated in Table 4, a well constructed FT must display all the possible scenarios and combination of failures that can result in the critical event [3], taking into consideration the relationships between events.

In the present methodology, this will allow the analysis of all the causes that may be contributing to the presence of pathogenic protozoa in source waters, 
Table 4: Qualitative risk analysis methods (QRAM).

\begin{tabular}{|c|c|c|c|c|}
\hline Method & Brief description & 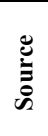 & 离 & References \\
\hline Risk matrices & $\begin{array}{l}\text { Allows the ranking of hazardous events according to urgency of } \\
\text { intervention. Places each hazardous event in a risk matrix } \\
\text { according to its consequence and likelihood, which are measured } \\
\text { quantitatively in discrete categories. }\end{array}$ & $\checkmark$ & $\checkmark$ & {$[5,29,30]$} \\
\hline $\begin{array}{l}\text { Preliminary } \\
\text { Hazard } \\
\text { Analysis } \\
\text { (PHA) }\end{array}$ & $\begin{array}{l}\text { Lists hazards and hazardous events by taking into account system } \\
\text { characteristics like used materials, used equipment, operation } \\
\text { conditions, system layout, etc. This method is complete by } \\
\text { identifying the likelihood of certain accident with the assessment } \\
\text { of possible health damages and treatment measures. }\end{array}$ & $\checkmark$ & $\checkmark$ & {$[28,29]$} \\
\hline $\begin{array}{l}\text { FMEA/ } \\
\text { FMECA }\end{array}$ & $\begin{array}{l}\text { These two methods identify possible failure modes of systems, } \\
\text { processes or its components and the possible outcomes of these } \\
\text { failures. It also identifies ways of preventing or minimizing these } \\
\text { effects. The FMECA method extends the scope of FMEA because } \\
\text { it allows the ranking of the identified failure modes according to } \\
\text { their importance or ugency. }\end{array}$ & $\mathrm{X}$ & $\checkmark$ & {$[28,29,30]$} \\
\hline $\begin{array}{l}\text { Fault Tree } \\
\text { Analysis } \\
\text { (FTA) }\end{array}$ & $\begin{array}{l}\text { Method used to identify and analyze factors that can concur to } \\
\text { a certain undesirable event and its various ways of occurring. It } \\
\text { uses a logic diagram that represents potential relations between } \\
\text { critical events and their causes. One of its advantages is allowing } \\
\text { the identification of any combination of failures that when } \\
\text { happening isolated are not critical, but when happening together } \\
\text { may be. }\end{array}$ & $\checkmark$ & $\checkmark$ & {$[28,29,30]$} \\
\hline $\begin{array}{l}\text { Reliability } \\
\text { Block } \\
\text { Diagram } \\
\text { (RBD) }\end{array}$ & $\begin{array}{l}\text { Describes the way a system works through logic connections } \\
\text { between its components. It presents two basic structures: a } \\
\text { system that works only if all of its components are working is } \\
\text { represented by a series structure; a system that works when only } \\
\text { one of its components is working is represented by a parallel } \\
\text { structure. Each component is represented by a block and when the } \\
\text { initial point and the end point of the diagram are connected the } \\
\text { system is working correctly. }\end{array}$ & $\checkmark$ & $\checkmark$ & {$[29,30]$} \\
\hline $\begin{array}{l}\text { Event Tree } \\
\text { Analysis } \\
\text { (ETA) }\end{array}$ & $\begin{array}{l}\text { Logic diagram that starts with an initial event, potentially } \\
\text { hazardous, and allows the study of its progression since its } \\
\text { beginning to the final consequences. The sequence of events is } \\
\text { conditioned by safety barriers or control procedures. The } \\
\text { consequences are met assuming these barriers either fail or succeed. }\end{array}$ & $\checkmark$ & $\checkmark$ & {$[29,30]$} \\
\hline $\begin{array}{l}\text { Bow-Tie } \\
\text { Diagram }\end{array}$ & $\begin{array}{l}\text { This method is used to show an array of possible causes and } \\
\text { consequences of a certain risk. Its output is a diagram that } \\
\text { displays the main ways from the causes to the risk and from the } \\
\text { risk to its consequences, with the barriers that can help to prevent } \\
\text { either that risk from existing (barriers in the pathway causes to risk) } \\
\text { or its consequences to happen (barriers in the pathway risk to } \\
\text { consequences). }\end{array}$ & $\checkmark$ & $\checkmark$ & {$[28,29]$} \\
\hline
\end{tabular}


taking into consideration the existence of complementary events, as defined before. The top critical final event of the FT (the one that all the hazardous events will eventually lead to) is the presence of pathogenic protozoa in source water.

An ET is equally a logic diagram. It will start from an initial event, which in the present situation, is the same as the top critical event of the FT, and will end in the consequences that the event can bring. In between, there will stand the possible barriers amidst the initial negative event and its possible consequences $[29,30]$, which will be the possible water treatment system failure presented above.

These barriers will either exist or not and this will lead to different consequences. If the success or failure of one barrier depends on combinations of various factors, a FTA can be applied to that barrier. Therefore, it will be possible to study the consequences of the presence of pathogenic protozoa in source water that can be submitted to different water treatment processes.

This strategy will admit a schematic planning of all the occurrences in the watershed and in the water treatment step that can contribute to the potential presence of pathogenic protozoa in drinking water. Its basic structure can be seen in Figure 2.

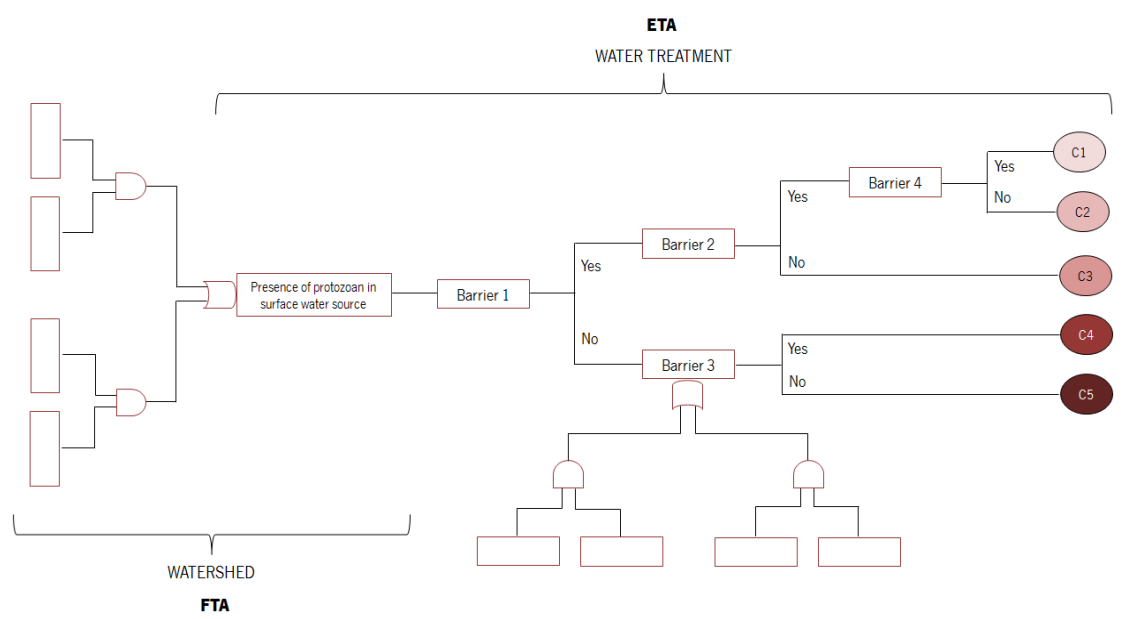

Figure 2: $\quad$ Risk analysis methodology based on FT and ET analysis.

\subsection{Risk treatment}

Risk treatment is the process of selecting and applying risk reduction measures and barriers. In the present study, if the earlier stage reveals unacceptable risks for human health, it will be of paramount importance to provide measures that may act in one or both of the analyzed strategies: water sources protection and improvement of water treatment plan (WTP) performance related to protozoa removal. 
The measures will be selected according to the outcomes of the earlier stages and should be implemented by order of importance. Considering the level of watershed protection, pathogen sources and/or pathways that are contributing the most to the concentration of protozoa in surface waters should be the ones to be treated first [10]. However, some watershed protection measures may not be of the exclusive responsibility of the water supplier because these may involve territorial planning measures and others that may directly involve farmers and livestock producers.

Therefore, it is important to raise awareness and promote best practices among the general population with emphasis on this subject, and to promote the collaboration between different organizations. Nevertheless, even if achieving an efficient watershed protection, and in the light of the multi-barrier approach, water treatment must not be neglected.

This approach is expected to create a certain redundancy that guarantees that the water has always the proper safety degree even if one of the barriers fails. The water treatment processes should be able to adapt as best as possible to fluctuations in raw water quality. These variations will affect treatment success and consequently, the risk associated. Moreover, a change in one process effectiveness may affect all the following processes in the water treatment train [26], compromising treated water quality.

Thus, together with effective water treatment processes in the removal/inactivation of pathogenic protozoa from the water, it is necessary to undertake correct monitoring of these processes towards maximum water quality by guaranteeing operation control and prompt intervention when failures occur. Whichever the treatment risk measures applied, their employment should be followed by a cyclic process of risk reanalysis to assess the new level of risk, ergo the treatment measures efficiency [28].

\section{Discussion}

The first steps were made towards developing a risk management methodology to infer and control the presence of pathogenic protozoa in drinking water systems. In this strategy, more focus was given to the steps of hazard identification, risk analysis and risk treatment, being these the key steps for risk management and those that more contribute for the effective control of this parasites. Thus, all the related hazardous events were identified either when considering water source protection or water treatment systems and the strategy for risk analysis and risk treatment was defined.

When regarding risk analysis, a qualitative methodology was chosen because of the lack of valid numerical data that restrains the use of more frequently used quantitative approaches. Moreover, the development of a quantitative approach to risk analysis of the presence of pathogenic protozoa in raw and drinking water allows for different methods of risk assessment other than the worldwide common approaches. Indeed, they usually use the QRMA to assess the likelihood of daily/annual infection based on estimating protozoa concentration 
in raw and drinking water, daily water consumption and human immune response to these parasites [20].

Assuming that the number of worldwide drinking water systems that can provide a representative data sets regarding this pathogenic parasites is not a majority - mostly because of the cost of direct analysis - there is certainly a need for methods that promote not an extensive statistical analysis, but a risk analysis that focuses directly on the major water contamination vectors and drinking water systems weaknesses. So, this kind of methodology enables water supply utilities an easily and cost effectively understanding of how and where they should preferentially act.

Here, the authors studied the relationship between the causes associated with known outbreaks in order to assess their respective contributions to the outbreak occurrence. They chose to use an FT analysis because it would enable the consideration of groups of events as different scenarios, considering that an event by itself may not trigger an outbreak, but its combination with other or others may lead to it.

A similar methodology based on the FTA was already applied to sixty one outbreaks that had occurred in the European Union between 1990 and 2005 [16]. The authors have concluded that the FT could be tailored to suit different drinking water systems, pathways and causative factors including human actions, mechanical failures, and additional point and non-point contaminant sources. The presented methodology aims not only to analyze past outbreaks, but mainly to prevent them. To conclude its development in the nearby future, it will be tested using selected case studies to gauge its effectiveness and will, if needed, suffer the necessary adjustments. For this task to be completed the maximum possible data will be collected regarding both the river basin characteristics and the existent water treatment systems. It shall integrate information concerning all the identified hazardous events such as number and location of livestock, livestock access to water, wild life existence and access to water, sewage discharge points, occurrence of CSO and all others previously identified.

A factor of paramount importance is the occurrence of precipitation as this shall increase protozoa concentration in raw water. Corresponding data will be collected and, if possible, crossed over with water analysis results regarding these parasites. This shall enable the accessing of its influence in the transport of organic matter into the water. As to the water treatment system, information shall be gathered concerning the existing treatment schemes, the efficiencies of protozoa removal processes and its operational and monitoring conditions. Despite being still in progress, it is expected that this methodology will help in protecting Portuguese drinking water systems against this recent microbiologic threat.

\section{Acknowledgements}

This work is funded by National Funds through FCT - Foundation for Science and Technology through the Project PEst-OE/ECI/UI4047/2011. The authors also thank Eng. Cristina Danko for her useful and kind assistance in the revision of this paper. 


\section{References}

[1] OECD/WHO, Assessing Microbial Safety of Drinking Water: Improving approaches and methods, OECD/WHO, UK, 2003.

[2] Franco, R.M.B., Waterborne protozoa: relevance for public health. Rev Panam Infectol, 9 (4), pp. 36-43, 2007. (in Portuguese)

[3] WHO, Water Quality: Guidelines, standards and health, WHO, UK, 2001.

[4] Osewe, P., Addiss, D.G., Blair, K.A., Hightower, A., Kamb, M.L., Davis, J.P., Cryptosporidioses in Wisconsin: A case-control study of post-outbreak transmission. Epidemiol. Infect., 117, pp. 297-304, 1996.

[5] WHO, Guidelines for Drinking-water Quality - ${ }^{\text {th }}$ Edition, WHO, 2011.

[6] USEPA, Cryptosporidium: Drinking Water Health Advisory. USA, 2001.

[7] Karanis, P., Kourenti, C., Smith, H., Waterborne transmission of protozoan parasites: a worldwide review of outbreaks and lessons learnt. Journal of Water and Health, 05 (1), pp. 1-38, 2007.

[8] Medema, G.J., Cryptosporidium and Giardia: new challenges to the water industry. PhD Thesis, Faculty of Science, University of Utrecht, Utrecht, The Netherlands, 1999.

[9] Keeley, A. and Faulkner, B.R., Influence of land use and watershed characteristics on protozoa contamination in a potential drinking water resources reservoir. Water Research, 42, pp. 2803-2813, 2008.

[10] WHO, Water safety plans: Managing drinking-water quality from catchment to consumer, WHO, Switzerland 2005.

[11] NHMRC/NRMMC, Australian Drinking Water Guidelines 6, Australian Government, Australia, 2011.

[12] ISO 31000:2009, Risk management - Principles and Guidelines. The International Organization for Standardization, Switzerland, 2009.

[13] Ruecker, N.J., Braithwaite, S.L., Topp, E., Edge, T., Lapen, D.R., Wilkes, G., Robertson, W., Medeiros, D., Sensen, C.W., Neumann, N.F., Tracking Host Sources of Cryptosporidium spp. in Raw Water for Improved Health Risk Assessment. Applied and Environ. Microbiology, pp. 3945-3957, 2007.

[14] Scottish Water, The Cryptosporidium (Scottish Water) Directions 2003, The Scottish Government, Scotland, 2003.

[15] Ferguson, C.M., Croke, B.F.W., Beatson, P.J., Ashbolt, N.J., Deere, D.A., Development of a process-based model to predict pathogen budgets for the Sydney drinking water catchment. Journal of Water and Health, 05 (2), pp. 108-208, 2007.

[16] Risebro, H.L., Doria, M.F., Andersson, Y., Medema, G., Osborn, K., Schlosser, O., Hunter, P.R., Fault tree analysis of the causes of waterborne outbreaks. Journal of Water and Health, 05 (Suppl. 1), pp. 1-18, 2007.

[17] Bryan, B.A., Kandulu, J., Deere, D.A., White, M., Frizenschaf, J., Crossman, N.D., Adaptive management for mitigating Cryptosporidium risk in source water: A case study in an agricultural catchment in South Australia. Journal of Envir. Management, 90, pp. 3122-3134, 2009. 
[18] Medema, G. J. and Schijven, J. F., Modelling the sewage discharge and dispersion of Cryptosporidium and Giardia in Surface Water. Water Research, 35 (18), pp. 4307-4316, 2001.

[19] Arnone, D.R. and Walling, J.P., Evaluating Cryptosporidium and Giardia concentrations in combined sewer overflow. Journal of Water and Health, 04 (2), pp. 157-165, 2006

[20] WHO, Risk Assessment of Cryptosporidium in Drinking Water, WHO, Switzerland 2009.

[21] Davies, C.M., Fergunson, C.M., Kaucner, C., Krogh, M., Altavilla, N., Deere, D.A., Ashbolt, N.J., Dispersion and Transport of Cryptosporidium Oocysts from Fecal Pats under Simulated Rainfall Events. Applied and Environmental Microbiology, pp. 1151-1159, Feb. 2004.

[22] USEPA, Alternative Disinfectants and Oxidants Guidance Manual. USEPA, USA, 1999.

[23] Betancourt, W.Q. and Rose, J.B, Drinking water treatment processes for removal of Cryptosporidium and Giardia. Veterinary Parasitology, 126, pp. 219-234, 2004.

[24] Goss, M. and Richards, C., Development of a risk-based index for source water protection planning, which supports the reduction of pathogens from agricultural activity entering water resources. Journal of Environmental Management, 87, pp. 623-632, 2008.

[25] Beuken, R., Reinoso, M., Sturm, S., Kiefer, J., Bondelind, M., Áström, J., Lindhe, A., Losém, L., Pettersson, T., Machenbach, I., Melin, E., Thorsen, T., Eikebrokk, B., Hokstad, P., Røstum, Niewersch, C., Kirchner, D., Kozisek, F., Gari, W., Swartz, C., Menaia, J., Identification and description of hazards for water supply systems. TECHNEAU Project, 2008.

[26] WHO, Water Treatment and Pathogen Control: Process efficiency in achieving safe drinking water. WHO, UK, 2004.

[27] AS/NZS 4360:2004, Risk Management. Joint Technical Committee OB-007. Council of Standard Australia and Council of Standards New Zealand, Australia and New Zealand, 2004.

[28] IEC/FDIS 31010, Risk management - Risk assessment techniques. International Electrotechnical Commission. Switzerland, 2009.

[29] Rosén, L., Hokstad, P., Lindhe, A., Sklet, S., Røstum, J., Generic Framework and Methods for Integrated Risk Management in Water Safety Plans. TECHNEAU Project, 2007.

[30] Hokstad, P., Røstum, J., Sklet, S., Rosén, L., Pettersson, T.J.R., Lindhe, A., Sturm, R., Beuken, R., Kirchner, D., Niewersch, C., Methods for risk analysis of drinking water systems from source to tap-Guidance report on Risk Analysis. TECHNEAU project, 2009. 